\title{
Plant Associations within the Interior Valleys of the Umpqua River Basin, Oregon
}

\author{
WINSTON PAUL SMITH
}

Eleven plant associations were identified and characterized according to the frequency, percent cover, and relative dominance of the herbaceous and woody species among the vegetative strata, including stem density, dinmeter breast height (dbh), and basal area for tree species: Cynosurus echinatus/Taeniatherum asperum; Bromus mollis/Cynosurus echinatus; Rhus diversiloba/Cynosurus echinatus; Quercus garryana/Rhus diversiloba/Taeniatherum asperum/Cynosurus echinatus; Quercus garryana/Rhus diversiloba/Dactylis glomerata; Pseudotsuga menziesii/Quercus garyana/Rhus diversiloba/Polyxtichmmmitum; Quercus garyana/Arbutus menziesii/Rhus diversiloba/Cynosurus echinatus; Arbutus menziesii/Rhus diversiloba/Festuca arundinacea; Quercus garryana/Fraxinus latifolia/Rosa elganteria/Juncus effusus; Pseudotsuga menziesii/Corylus cornuta/Cynosurus echinatus. The intensity and duration of recent disturbance distinguished early seral stages which were characterized by a paucity of native shrub and herbaceous species and an abundance of annual invaders in the understory. The primary forces that influenced existing plant assemblages were fire and more recently agricultural practices, especially among grasslands and savannas. Grasslands without recent livestock use exhibited greater species diversity, supporting more species and a more homogeneous distribution of relative abundance among species.

There are very few descriptive data for the vegetation of the Interior Valley Zone of western Oregon (Franklin and Dyrness 1973). The interior valleys of southwestern Oregon represent a climatic and botanical transition zone between the mesic lowlands of the Willamette Valley in central-and north-western Oregon and the more xeric lowlands within the interior valleys of northern California. Several herbaceous and woody plant species characteristic of the respective ecosystems exhibit corresponding northern and southern limits in geographic distribution within the interior valleys of the Umpqua and Rogue River Basins (Hitchcock and Cronquist 1973). The result is a unique assemblage of herbaceous and woody plant species identifiable as distinct plant associations (i.e., communities of similar floristic composition, physiognomy, and uniform habitat conditions [Muller-Dombois and Ellenberg 1974]).

The need for a quantitative ecological approach to range evaluation and management was first espoused by Dyksterhuis (1949); and more detailed description of principles, methodology, and application appeared in subsequent publications (Dyksterhuis 1958a, 1958b). More recently, Gates (1974) has advocated the application of plant succession and other ecological concepts to rangeland resource inventories; he recognized that range evaluation must be based upon "potential vegetation aggregations"(i.e., the condition of the existing plant community with respect to the native seral associations) rather than the potential forage production.

This paper examines data collected during an ecological study within the interior valleys of the North Umpqua River. The overall

\footnotetext{
The author is a ssistant professor, Department of Biological Sciences, Southeastern Louisiana University, Hammond, Louisiana 70402.

This study was supported by the Oregon State University Agricultural Experiment Station, the Wildlife Management Institute, the American Petroleum Institute, the National Rifle Association Grants-In-Aid Program, Oregon State University Computer Center and the Douglas County Board of Commissioners, Douglas County, Oregon. D.K. Brown, B.E. Coblentz, and W.C. Krueger reviewed the manuscript and made suggestions that ultimately improved the quality of this paper. This is Oregon Agricultural Experiment Station Technical Report 7098.

Manuscript accepted February 1, 1985.
}

goal of this endeavor was to quantitatively characterize the identifiable plant associations within the study area. Specific objectives included determining percent cover, frequency of occurrence and relative dominance of the plant species within the 3 vegetative strata.

\section{Methods and Materials}

The study area was situated along the North Umpqua River between Winchester and Glide, Douglas County, Oregon (Fig. 1) and encompassed 2,745 ha. The topography was typical of the Umpqua and Rogue interior valleys with numerous small mountains and rolling foothills producing a mosaic of small valleys and ridges. The elevation ranged from $135 \mathrm{~m}$ along the North Umpqua River to $505 \mathrm{~m}$-a ridge crest which formed the southern boundary of the study area (Fig. 1).

Temperatures along the interior Umpqua valleys were moderate; the mean monthly minimum and maximum temperatures were $4.9^{\circ} \mathrm{C}\left(\mathrm{s}_{\mathrm{x}}=0.34\right)$ in January and $20.2^{\circ} \mathrm{C}\left(\mathrm{s}_{\mathrm{x}}=0.27\right)$ in August, respectively (U.S. Department of Commerce 1955-1980). The mean annual temperatue $\left(12.2^{\circ} \mathrm{C}, \mathrm{s}_{\mathrm{z}}=0.24\right)$ rarely fluctuates dramatically among years, but annual precipitation may vary considerably (e.g., $55.9 \mathrm{~cm}$ in 1978 as compared to $90.4 \mathrm{~cm}$ in 1979). Mean annual precipitation was $84.1 \mathrm{~cm}\left(\mathrm{~s}_{x}=3.07\right)$ with an average of 67.8 cm falling October-March, producing wet winters and semidrought summers. Snow cover is uncommon and rarely persists for more than a few days.

A general reconaissance of the study area during the initial field season, May-August 1978, provided the basis for subdividing the existing Quercus woodland community into 11 distinct plant associations. Differences in species composition and structure (e.g., absence or presence of one of the vegetative strata) served as the primary criteria for delineating plant assemblages. Botanical nomenclature followed Hitchcock and Cronquist (1973) except for Gramineae where Hitchcock (1971) were consulted. The arcsin transformation was employed with percentage data exhibiting a wide range of values, whereas the square root transformation was used with percentages between 0 to 20 or 80 to 100 . A probability level of less than 0.05 was accepted as indicating statistical significance.

Full time field studies resumed May 1979 and continued through September 1979. Whenever possible, 3 replicates of each association were sampled. The number of plots per sample ( $n=50$ for each replicate) was derived from the existing variation in preliminary samples (Zar 1984:132). A random-systematic sampling scheme was devised such that plots were located along a predefined transect that began at a randomly selected starting point. The distance between plots was adjusted to ensure that the entire replicate site was included in the sampling procedure.

Herbaceous cover (percent crown cover) was estimated for each species occurring within a 2 by 5 dm-plot (Daubenmire 1959). Percent frequency of occurrence and relative dominance (as determined from percent crown cover) of each species were computed. Shrub crown cover was estimated with the line-intercept method (Canfield 1941). Intercept lines were incorporated within the general sampling scheme, extending from each plot site along the transect. The intercept of each shrub species along a $20-\mathrm{m}$ tape was measured to the nearest centimeter. The total amount of intercept was summed for each line; cover, botanical composition 


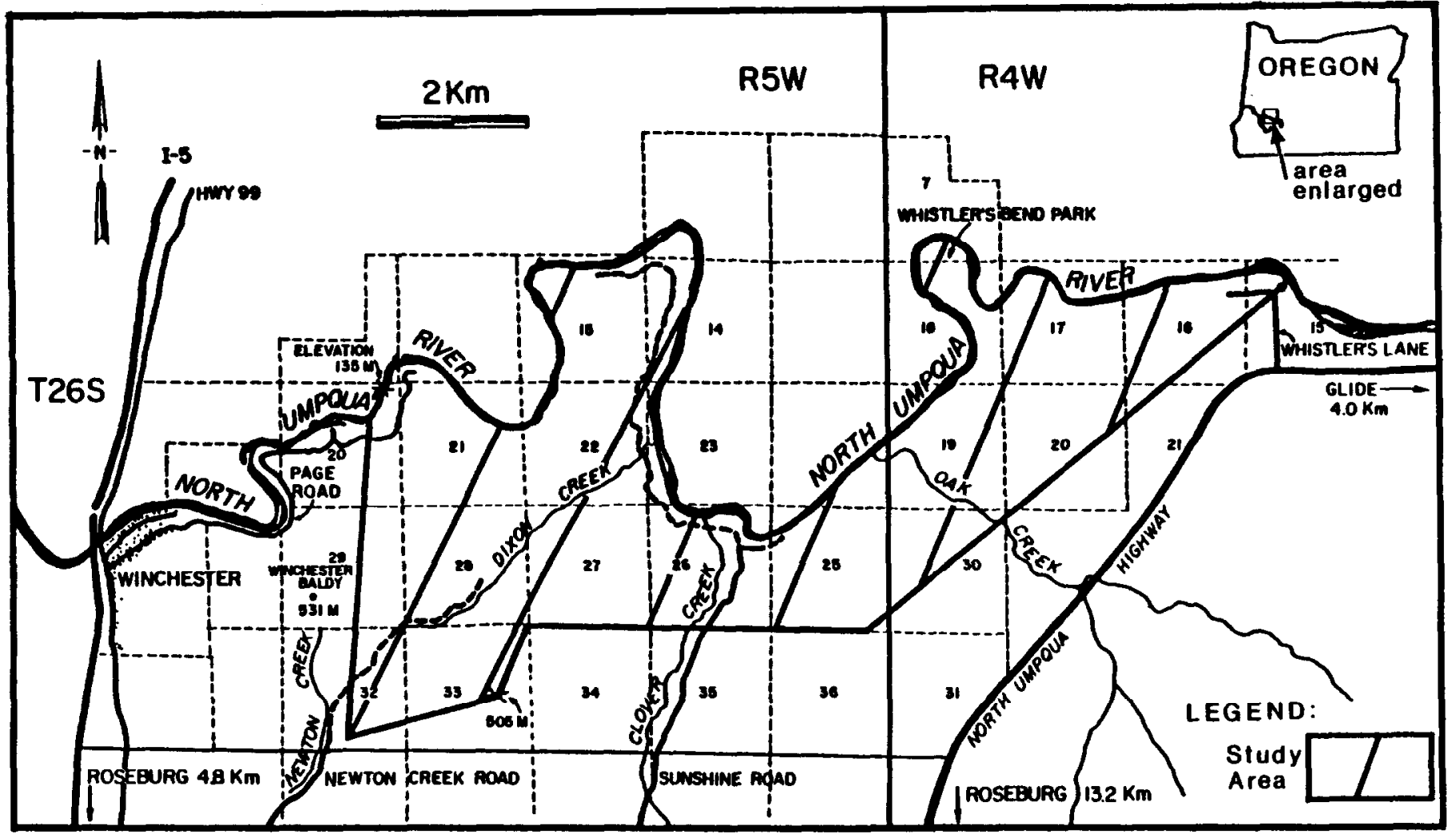

Fig. 1. The 2,745-hectare study area (hatched region) situated along the North Umpqua River between Winchester and Glide, Ore., May 1978-December 1980.

and relative dominance were computed accordingly (Pieper 1978).

An estimate of canopy cover was obtained at each of the 50 plots with a forest densiometer (Lemmon 1956). The point-centered quarter method (Cottam and Curtis 1956) was employed to estimate tree density and relative dominance (as determined from basal area); the center of a plot served as the sampling point. The distance (in centimeters) to the nearest tree in each of the 4 quadrats, tree species, and its diameter at breast height (dbh) were recorded.

Vertical density of the vegetation was estimated at each of the 50 plots with a density board (Wight 1938). A reading was taken from a point $20 \mathrm{~m}$ beyond each plot along the transect.

\section{Results}

Each of the plant associations was named with the scientific names of the dominant and co-dominant plant species occurring within the corresponding vegetative strata. Subsequent references to each of the associations in the text will use only generic names.

\section{Description of Plant Associations}

Cynosurus echinatus/ Taeniatherum asperum. Preliminary data indicated discernible differences between pasturelands and grasslands (areas not recently exposed to livestock) and justified separate descriptions of the corresponding plant associations. Cynosurus/Taeniatherum associations were pasturelands experiencing a rotational grazing schedule by cattle and sheep and comprised $29.7 \%$ ( $815 \mathrm{ha})$ of the study area. The grasses and forbs were distributed uniformly throughout with $94 \%$ of 150 plots exhibiting $\geq 62 \%$ cover. The mean herbaceous cover was $81.1 \%\left(s_{x}=1.48\right)$ but the mean vertical density index was $20.5(s=0.04$, minimum value $=21$ ), reflecting the general scarcity of tall herbaceous vegetation. Hedgehog dogtail (Cynosurus echinatus), medusahead wildrye (Taeniatherum asperum), and soft chess brome (Bromus mollis) comprised $49.2 \%$ of the total herbaceous cover. California oatgrass (Danthonia californica) was the only common native grass, occurring in $37 \%$ of the plots and representing an average of $5.7 \%$ cover. Many of the pasturelands were subjected to periodic controlled burning and seeded to sub-clover (Trifolium subterraneum), perennial ryegrass (Lolium perenne), and tall fescue (Festuca arundinacea).

Bromus mollis/Cynosurus echinatus. The Bromus/Cynosurus association represented natural prairies, grass balds, and pasturelands that had not experienced recent livestock use. These areas were typically free of disturbance except natural fires, and comprised $3.9 \%$ ( $107 \mathrm{ha}$ ) of the study area. The vegetation was comparably dense and homogeneous; $95 \%$ of 100 plots demonstrated $\geq 62 \%$ cover and the mean index of vertical density was $19.6\left(\mathrm{~s}_{\mathrm{x}}=\right.$ 0.12 ). Mean herbaceous cover was $78.1 \%\left(s_{x}=1.69\right)$. Soft chess brome, hedgehog dogtail, and perennial ryegrass accounted for $43.6 \%$ of the cover. Native grasses included California oatgrass, pine bluegrass (Poa scabrella), Sandberg's bluegrass ( $P$. sandbergii), and blue wildrye (ELymus glaucus).

Rhus diversiloba/Cynosurus echinatus. Rhus/Cynosurus comprised $4.4 \%$ (121 ha) of the study area. Typically, these areas supported very few trees and exhibited dense shrub cover $\bar{x}=$ $34.4 \%, s_{x}=1.76$ ). Poison oak (Rhus diversiloba) was dominant, occurring in $98 \%$ of the sampling points and accounting for $96.2 \%$ of the cover. Mean herbaceous cover was $73.1 \%\left(s_{\mathrm{f}}=1.77\right)$ and the mean vertical density index was $10.1\left(s_{z}=0.67\right)$. New-growth poison oak was $36.8 \%$ of the ground cover; the dominant grass was hedgehog dogtail.

Quercus garryana/Rhus diversiloba/Taeniatherum asperum/Cynosurus echinatus. This association was an oak-woodland/grassland interspersion with an average tree density of $95.6 \mathrm{stems} / \mathrm{ha}$ (s $=20.6$ ) and occupied $13.2 \%$ (362 ha) of the study area. Mean dbh was $32.9 \mathrm{~cm}\left(\mathrm{~s}_{\mathrm{x}}=0.87\right)$, and the mean canopy cover was $25.5 \%\left(\mathrm{~s}_{\mathrm{z}}=\right.$ 2.94). The average shrub cover was $5.9 \%\left(s_{x}=1.33\right)$; poison oak 
Table 1. Tree density, mean dbh, mean basal area per ha, vertical density index and mean percent cover of the tree, shrub and herbaceous strata for each of the plant associations on the study area, May-September 1979.

\begin{tabular}{|c|c|c|c|c|c|c|c|}
\hline \multirow[b]{2}{*}{ Plant associations } & \multicolumn{7}{|c|}{ Stand Characteristics } \\
\hline & Canopy cover & Tree density & DBH & Basal area & Shrub cover & Herbs cover & $\begin{array}{c}\text { Vertical } \\
\text { density index }\end{array}$ \\
\hline $\begin{array}{l}\text { Cynosurus echinatus/ } \\
\text { Taeniatherum asperum }\end{array}$ & \% & stems/ha & cm & $\mathrm{m}^{2} / \mathrm{ha}$ & $\%$ & $\begin{array}{c}\% \\
81.1 d\end{array}$ & $20.5 \mathrm{e}$ \\
\hline Bromus mollis/Cynosurus echinatus & - & - & - & - & - & $78.1 \mathrm{~cd}$ & $19.6 \mathrm{e}$ \\
\hline Rhus diversiloba/Cynosurus echinatus & - & - & - & - & $34.4 d$ & $73.1 \mathrm{~cd}$ & $6.8 \mathrm{bc}$ \\
\hline $\begin{array}{l}\text { Quercus garryana/ Rhus diversiloba/ } \\
\text { Taeniatherum asperum/ } \\
\text { Cynosurus echinatus }\end{array}$ & $25.5 \mathrm{a}$ & $10 \mathrm{a}$ & $32.9 \mathrm{bc}$ & $8.1 \mathrm{a}$ & $5.9 \mathrm{a}$ & $76.8 \mathrm{~cd}$ & $18.4 \mathrm{de}$ \\
\hline $\begin{array}{l}\text { Quercus garryana/ } \\
\text { Rhus diversiloba/ } \\
\text { Taeniatherum asperum }\end{array}$ & $69.9 b$ & $665 b$ & $22 . \operatorname{lab}_{\mathrm{c}}$ & $25.5 b$ & $6.1 \mathrm{a}$ & $71.3 \mathrm{~cd}$ & $\underset{\mathrm{e}}{14.2 \mathrm{~cd}}$ \\
\hline $\begin{array}{l}\text { Quercus garryana/ Rhus diversiloba/ } \\
\text { Dactylis glomerata }\end{array}$ & $90.3 b$ & $1266 c$ & $21.2 \mathrm{ab}$ & $44.7 \mathrm{~d}$ & $47.6 \mathrm{~d}$ & $58.4 \mathrm{dc}$ & $\underset{c}{9.3 \mathrm{ab}}$ \\
\hline $\begin{array}{l}\text { Pseudotsuga menziesii/ } \\
\text { Quercus garryana/ } \\
\text { Rhus diversiloba/ } \\
\text { Polystichum munitum }\end{array}$ & $89.7 b$ & $1364 \mathrm{c}$ & $\underset{c}{21.3 a b}$ & $49.5 \mathrm{~d}$ & $21.2 b$ & $30.5 \mathrm{ab}$ & $5.2 \mathrm{~b}$ \\
\hline $\begin{array}{l}\text { Quercus garryana } \\
\text { Arbutus menziesii/ } \\
\text { Rhus diversiloba/ } \\
\text { Cynosurus echinatus }\end{array}$ & $78.0 \mathrm{~b}$ & $1283 \mathrm{c}$ & $15.7 \mathrm{ab}$ & $24.8 b$ & $31.7 \mathrm{c}$ & $\underset{c}{46.5 a b}$ & $\underset{\mathrm{c}}{7.3 \mathrm{ab}}$ \\
\hline $\begin{array}{l}\text { Arbutus menziesii/ } \\
\text { Rhus diversiloba/ } \\
\text { Festuca arundinacea }\end{array}$ & $79.3 b$ & $3762 d$ & $10.3 \mathrm{a}$ & $31.4 \mathrm{bc}$ & $28.4 \mathrm{c}$ & $25.0 \mathrm{a}$ & $3.0 \mathrm{a}$ \\
\hline $\begin{array}{l}\text { Quercus garryana/ } \\
\text { Fraxinus latifolia/ } \\
\text { Rosa elganteria/ } \\
\text { Juncus effusus }\end{array}$ & $81.5 b$ & $622 b$ & 28. $\underset{c}{\mathrm{lab}}$ & $38.6 \mathrm{~cd}$ & $4.6 \mathrm{a}$ & $69.1 \mathrm{~cd}$ & $10.9 \mathrm{~cd}$ \\
\hline $\begin{array}{l}\text { Pseudotsuga menziesii/ } \\
\text { Corylus cornuta/ } \\
\text { Cynosurus echinatus }\end{array}$ & $92.3 b$ & $541 b$ & $41.8 \mathrm{c}$ & $74.2 \mathrm{~d}$ & $5.8 \mathrm{a}$ & $21.4 \mathrm{a}$ & $12.0 \mathrm{de}$ \\
\hline
\end{tabular}

Within columns, values that share common letters are not different ( $P>0.05$; Dunn's multiple comparison test, Daniel 1978 ).

accounted for $95 \%$ of the midstory. Mean herbaceous cover was $76.8 \%\left(s_{x}=2.32\right)$; medusahead wildrye and hedgehog dogtail were co-dominant. The mean index of vertical density was $1.84\left(\mathrm{~s}_{\mathrm{x}}=\right.$ 0.46).

Quercus garryana/Rhus diversiloba/Cynosurus echinatus. Quercus/Rhus/Cynosurus occupied $17.1 \%$ (469 ha) of the study area and represented relatively uniform-aged oak woodlands with a well-developed overstory and understory; the shrub layer was sparse and often absent. Mean canopy cover and herbaceous cover were $69.6 \%\left(s_{s}=2.21\right)$ and $71.3 \%(s=2.38)$, respectively; shrub cover averaged $6.1 \%\left(s_{z}=62.0\right)$ while the mean dbh was $22.1 \mathrm{~cm}\left(\mathrm{~s}_{\mathrm{z}}=\right.$ 0.59 ). Oregon white oak (Quercus garryana) and California black oak (Q. kelloggii) were co-dominant and accounted for $95 \%$ of the standing basal area. Poison oak and wild rose (Rosa elganteria) averaged $3.7 \%$ and $2.3 \%$ cover, respectively, and together accounted for $99 \%$ of the midstory. Hedgehog dogtail, California oatgrass and perennial ryegrass comprised $53.5 \%$ of the understory. The mean index of vertical density was $14.2\left(s_{z}=0.61\right)$.

Quercus garryana/ Rhus diversiloba/ Dactylis glomerata. Quercus/Rhus/Dactylis was an even-aged woodland with 3 welldeveloped vegetative strata and occupied $8.7 \%$ (239 ha) of the study area. The overstory was comparably dense with essentially a continuous canopy. The mean tree density was $1,266 \mathrm{stems} / \mathrm{ha}\left(\mathrm{s}_{\mathrm{x}}=\right.$ 118) while the average canopy cover was $90.3 \%\left(s_{x}=1.53\right)$. Oregon white oak and California black oak were $69.2 \%$ and $24 . \%$ of the existing basal area, respectively; mean dbh was $21.2 \mathrm{~cm}\left(\mathrm{~s}_{\mathrm{x}}=0.66\right)$. Shrub cover averaged $47.6 \%\left(s_{x}=3.34\right)$; poison oak and wild rose occurred with a frequency of 0.72 and 0.52 , respectively, and together were $92 \%$ of the midstory cover. New-growth poison oak accounted for $32.2 \%$ of the understory cover which averaged $58.4 \%$ ( $\left.s_{x}=2.25\right)$; orchardgrass (Dactylis glomerata) and hedgehog dogtail were co-dominant grasses. The mean vertical density index was 9.3 $\left(\mathrm{s}_{\mathrm{x}}=1.01\right)$.

${ }^{x}$ Pseudotsuga menziesii/Quercus garryana/Rhus diversiloba/Polystichum munitum. This was a dense mixed oak-conifer stand averaging 1364 stems / ha $(s=136)$ and occupied $11.3 \%(310 \mathrm{ha})$ of the study area. The mean $\mathrm{dbh}$ was $21.5 \mathrm{~cm}\left(\mathrm{~s}_{\mathrm{x}}=0.78\right)$ and the average canopy cover was $89.7 \%\left(s_{x}=1.72\right)$. Douglas-fir (Pseduotsuga menziesii)and Oregon white oak were co-dominant, accounting for $79.1 \%$ of the existing basal area. Mean shrub cover was $21.2 \%(s=3.20)$; poison oak was $94.9 \%$ of the midstory. Herbaceous cover averaged $30.5 \%\left(s_{x}=2.99\right)$; newgrowth poison oak and swordfern (Polystichum munitum) were $58.3 \%$ of the understory while hedgehog dogtail was the dominant grass. The mean vertical density index was $5.15\left(s_{\mathrm{z}}=0.68\right)$.

Quercus garryana/Arbutus menziesii/ Rhus diversiloba / Cynosurus echinatus. On more xeric sites, many woodlands $(6.1 \%, 167$ ha) were co-dominant stands of Oregon white oak and Pacific madrone (Arbutus menziesii). Oak-madrone woodlands averaged $78.4 \%\left(s_{x}=2.04\right)$ canopy cover and supported a mean density of 1283 stems / ha $\left(s_{x}=81.2\right)$. Oregon white oak and Pacific madrone comprised $43.5 \%$ and $32.1 \%$ of the existing basal area, respectively; mean dbh per stem was $15.7 \mathrm{~cm}\left(s_{*}=0.36\right)$. The shrub layer averaged $31.7 \%\left(s_{x}=2.44\right)$ ground cover, poison oak was $90.1 \%$ of 
the shrub stratum. Mean herbaceous cover was $46.5 \%\left(s_{x}=2.59\right)$; new-growth poison oak accounted for the largest portion of the understory $(37.7 \%)$ while hedgehog dogtail was the dominant grass. The mean index of vertical density was $7.32\left(s_{s}=0.59\right)$.

Arbutus menziesii/ Rhus diversiloba / Festuca arundinacea. Fourteen percent ( $38.5 \mathrm{ha})$ of the study area was occupied by essentially monotypic stands of Pacific madrone. Arbutus/Rhus/Festuca were dense multi-layered woodlands averaging 3762 stems $/ \mathrm{ha}(\mathrm{s}=$ 750.0); the mean vertical density index was $3.04\left(s_{x}=0.25\right)$ and mean canopy cover was $79.3 \%\left(s_{x}=2.52\right)$. Poison oak occurred with a frequency of 0.71 and accounted for $97.9 \%$ of the shrub cover; total shrub cover averaged $28.4 \%\left(s_{x}=2.69\right)$. Herbaceous cover averaged $25.0 \%\left(s_{x}=2.69\right.$; tall fescue was dominant and accounted for $38.4 \%$ of the understory.

Quercus garryana/Fraxinus latifolia/ Rosa elganteria/Juncus effusus. Portions of the study area experienced perennial flooding. These areas together with poorly drained sites supported plant assemblages that were best characterized as a riparian association and comprised $3.1 \%(85 \mathrm{ha})$ of the study area. Some of the riparian areas were without an overstory (e.g., seeps, ephemeral streams), but typically Quercus/Fraxinus/Rosa/Juncus was a multi-layered woodland. The average tree density was 622 stems/ ha $\left(s_{x}=80.2\right)$ while mean dbh was $28.1 \mathrm{~cm}\left(\mathrm{~s}_{\mathrm{x}}=0.72\right)$. Within woodland sites, the canopy was essentially continuous but the overall mean canopy cover was $81.5 \%\left(s_{x}=2.21\right)$. Oregon white oak and Oregon ash (Fraxinus latifolia) were dominant and together accounted for $98.7 \%$ of the standing basal area. Mean shrub cover was $4.63 \%(\mathrm{~s}=$ 0.81 ); wild rose occurred within $36 \%$ of the sites and comprised $41.9 \%$ of the midstory. Owing to low-reaching canopies and a tall dense understory, the mean index of vertical density was $10.9\left(\mathrm{~s}_{\mathrm{x}}=\right.$ $0.63)$. Mean herbaceous cover was $69.1 \%\left(s_{x}=1.95\right)$; common rush (Juncus effusus) and tall fescue together accounted for $52.1 \%$ of the understory.

Pseudotsuga menziesii/Corylus cornuta/Cynosurus echinatus. Mixed conifer woodlands occupied the northern slopes at higher elevations and represented $1.1 \%$ (30.1 ha) of the study area. Pseudotsuga/Corylus/Cynosurus supported a continuous canopy $(\bar{x}=$ $92.3 \%, \mathrm{~s}=1.26$ ) with a sparse shrub layer $\bar{x}=5.8 \% ; \mathrm{s}=1.36$ ) and an intermittent understory $\bar{x}=21.4 \%, \mathrm{~s}_{\mathrm{x}}=2.49$ ). The average tree density was 541 stems/ha $\left(\mathrm{s}_{\mathrm{x}}=50.5\right)$ and mean dbh was $41.8\left(\mathrm{~s}_{\mathrm{x}}\right.$ 1.00). Douglas-fir was dominant and accounted for $91.0 \%$ of the existing basal area. Hazelnut (Corylus cornuta) and wild rose occurred most of ten within the midstory and represented $73.4 \%$ of the shrub cover. Hedgehog dogtail was the dominant herb, occurring in $63 \%$ of the plots and accounting for $39.5 \%$ of the understory. The mean index of vertical density was $12.0\left(s_{x}=0.84\right)$.

\section{Comparison of Community Parameters}

The species diversity of Cynosurus/Taeniatherum (2.66, Shannon Index, Zar 1984) and Bromus/Cynosurus (2.94) were different ( $P \leq 0.05$, test for differences between diversity indices, Zar 1984). Bromus/Cynosurus supported more species $(n=43)$ and exhibited a more uniform distribution of relative abundance among species as compared to Cynosurus / Taeniatherum $(n=39)$; corresponding homogeneity indices ( $\mathrm{Zar}$ 1984:34) were 0.781 and 0.721 , respectively.

The woodland associations differed ( $P \leq 0.05$; Kruskal-Wallis one-way ANOVA ranks test, Zar 1984) with respect to basal area/ha, shrub cover, vertical density, and herbaceous cover (Table 1). Arbutus/ Rhus/ Festuca displayed the highest ( $P \leq 0.05$ ) stem density, but Pseudotsuga/Corylus/Cynosurus supported the greatest $(P \leq 0.05)$ standing basal area (Dunn's multiple comparison test, Daniel 1978:212). Quercus/Rhus/Dactylis supported the densest $(P \leq 0.05)$ shrub stratum, but Arbutus/Rhus/Festua exhibited greater $(P \leq 0.05)$ vertical vegetation density (Dunn's multiple comparison test, Daniel 1978).

\section{Discussion}

The natural vegetation of the southwestern Oregon interior lowlands was classified as Quercus woodland community, typical of the Interior Valley Zone (Franklin and Dyrness 1973). The Quercus woodland associations along the interior North Umpqua River valleys represent a diverse array of plant assemblages ranging from largely open, sparsely stemmed savannas, to dense, multilayered forests. Species composition varied from pure Oregon white oak and California black oak stands to associations with an abundance of other hardwood and conifer associates, resembling the Quercus forest types of the Willamette Valley (Thilenius 1968). Differences in species composition probably reflect the typically more xeric nature of the interior Umpqua River Basin (U.S. Department of Commerce 1955-1980). California black oak, for example, was an important component of 3 southwestern Oregon woodland associations (and occurred within all 7 forest types), yet was not reported within any of the 4 oak woodland communities of the western Oregon central valley (Thilenius 1968). Also, Pacific madrone occurred much more frequently within the Umpqua Basin, often occurring in dense monotypic stands on the more xeric sites. Moreover, the oak woodland associations of the interior Umpqua valleys were most similar to the Quercus/Rhus community for the Willamette Valley, which typically occurred on the most xeric sites (Thilenius 1968).

The factors influencing phytosociological characteristics of presettlement southwestern Oregon were probably very similar to those desribed for the Willamette Valley (Thilenius 1968). Fire, both natural and human in origin, maintained oak-savannas in what was typically a forest environment; Indians frequently used fire as a management tool to create forest openings and encourage game (Douglas 1914). Subsequent to European settlement, there was an interruption of ground fires and many of the savannas were converted to young oak forests. Evidence of this phenomenon is provided by the comparable dense small Quercus stems that characterize the oak woodland/oak-savanna ecotone. The $\mathrm{dbh}$ of the young oak stems are comparable to Q. garryana of the Willamette Valley with a mean age of about 90 years (Thilenius 1968 ), which corresponds fairly well with early settlement of southwestern Oregon.

Since early settlement, logging, land clearance, grass seeding, controlled burning and livestock use have been very important factors influencing the phytosociology of existing Quercus woodland associations. This is particularly true of grasslands, savannas and young woodlands where an abundance of palatable forage and easy access combine to encourage more intense livestock use. This is clearly supported by the fact that important native perennials such as California oatgrass, red fescue ( $F$. rubra) and blue wildrye were replaced by the exotic annuals hedgehog dogtail, medusahead wildrye and ripgut brome (B. rigidus), invaders of intensively grazed grasslands. Some of the grasslands have experienced less intensive livestock use and/or have been released from grazing pressure for a longer period. These pasturelands supported considerably more native herbaceous species and were less of ten plagued with annual invaders overrunning the entire site. Moreover, the fact that the Bromus/Cynosurus association exhibited a greater diversity and homogeneity of plant species indicates that although livestock use can increase diversity via reducing competition among constituents, intense grazing will result in elimination of important perennials and encourage the establishment of less diverse plant assemblages dominated by annual invaders.

There was evidence that many of the conifer, mixed oak-conifer and older (as determined by dbh) monotypic stands of Pacific madrone were relatively undisturbed. The presence of a welldeveloped multi-layered stand with an abundance of native shrubs in the midstory and grasses and forbs throughout the understory characterized many older Quercus associations. Monotypic stands of Pacific madrone and oak-conifer supported Douglas-fir and ponderosa pine (Pinus ponderosa) in the overstory with younger stems in the midstory and recent regeneration. Also, these areas typically excluded or were relatively inaccessible to livestock. 
Conversely, Quercus/Rhus/Cynosurus and Rhus/Cynosurus associations lacked a well-developed shrub stratum and an overstory, respectively, and were maintained at earlier successional stages because of frequent controlled burning and easy access to livestock. Many of the existing oak-madrone and some of the monotypic Pacific madrone stands were apparently established following natural and/or man-induced disturbance. These stands were typically dense with small dbh stems and occurred on steep dry slopes; evidence of substantial recent erosion was also apparent. And as was true of the other disturbed sites, the seral shrub and forest associations supported few native woody and herbaceous species and were characterized by an understory dominated by annual invaders.

\section{Literature Cited}

Cenfield, R. 1941. Application of the line interception method in sampling ange vegetation. J. Forestry 39:388-394.

Cottam, G., and J.T. Curtis. 1956. The use of distance measures in phytosociological sampling. Ecology. 17:451-460.

Daniel, W.W. 1978. Applied non-parametric statistics. Houghton Mifflin Company. Boston.

Daubenmire, R.F. 1959. Canopy coverage method of vegetation analysis. Northwest Sci. 33:45-64.

Douglas, D. 1914. Journal kept by David Douglas during his travels in North America 1823-1827. W. Wesley and Son. London.

Dyksterhuis, E.J. 1949. Condition and management of range land based on quantitative ecology. J. Range Manage. 2:104-115.

Dyksterhuis, E.J. 1958a. Range conservation based on sites and condition classes. J. Soil and Water Conservation. 13:151-155.

Dyksterhuis, E.J. 1958b. Ecological principles in range evaluation. Bot. Rev. 4:253-272.
Franklin, J.F., and C.T. Dyrness. 1973. Natural vegetation of Oregon and Washington. USDA Forest Serv. Gen. Tech. Rep. PNW-8. Portland, Ore.

Gates, D.H. 1974. The use of range condition in rangeland ecosystem evaluation and management planning. Proc. 4th U.S.-Australian Range Workshop/Seminar, Alice Spring,, Australia.

Hitchcock, A.S. 1971. Manual of the grasses of the United States. Volumes 1 and 2. Dover Publications, Inc. New York.

Hitcheock, C.L. and A. Cronquist. 1973. Flora of the Pacific Northwest. U. Washington Press. Seattle.

Lemmon, P.E. 1956. A spherical densiometer for estimating forest overstory density. Forest Science. 2:314-320.

Mueller-Dombois, D., and H. Ellenberg. 1974. Aims and methods of vegetation ecology. John Wiley and Sons. New York.

Pieper, R.D. 1978. Measurement techniques for herbaceous and shrubby vegetation. New Mexico St. U. Bookstore, Inc. Las Cruces.

Sokal, R.R., and F.J. Rohlf. 1980. Biometry. W.H. Freeman and Company. San Francisco.

Steel, R.G.D., and J.H. Torrie. 1980. Principles and procedures of statistics. Second edition. McGraw-Hill Book Company, Inc. New York.

Thilenius, J.F. 1968. The Quercus Garryana forests of the Willamette Valley, Oregon. Ecology. 49:1124-1133.

United States Department of Commerce. 1955-1980. Climatological data, Oregon. Annual summary. National Oceanic and Atmospheric Administration, Environmental Data Service, Asheville, N.C. Volumes 61-86.

Wight, H.M. 1938. Field and laboratory technics in wildlife management. U. Michigan Press, Ann Arbor.

Zar, J.H. 1984. Biostatistical analysis. Second edition. Prentice-Hall, Englewood Cliffs, N.J.

\section{RANGELAND HYDROLOGY}

by Farrel A. Branson, Gerald F. Gifford, Kenneth G. Renard, and Richard F. Hadley

Unique in its emphasis on the hydrology of rangelands, primarily arid and semiarid lands, RANGELAND HYDROLOGY provides a text for one aspect of range management where none has existed before. This expanded Second Edition presents in-depth information for those who must manage rangeland or respond to questions about the impacts of land use practices on hydrology.

Included in the new Second Edition are a chapter on modeling with approaches to predicting the effects of land use, and a chapter on the rapidly developing field of snow pack management.

The 352-pages include 197 illustrations, providing rapid access to an assembly of data found nowhere else and useful in the preparation of environmental impact statements. Extensive bibliographic material with each chapter and a subject matter index add to the useableness of the book.

Range scientists and managers, soil conservationists, hydrologists, agricultural engineers, land reclamation specialists, wildlife managers, graduate and undergraduate students and their professors, as well as all interested in the hydrology of arid lands will find RANGELAND HYDROLOGY a valuable addition to their libraries. (352 pages paper laminated cover $\$ 15.00$ US) 